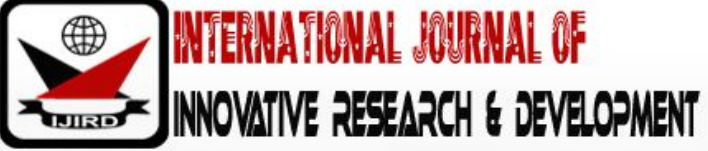

ISSN 2278 - 0211 (Online)

\section{Determination of Biocontrol Potentialusing Zooxanthellae as Indicator}

\author{
Anggreini Dian Naomi Rupidara \\ Lecturer, Department of Biology Education Study Program, \\ Artha Wacana Christian University, Kupang, Indonesia \\ Socorro Z. Parco \\ Lecturer, Department of Biology, Silliman University, Philippines
}

\begin{abstract}
:
Determination of biocontrol potential of bacteria isolated from diseased and healthy species of Acropora (Acroporaaspera and Acroporamillepora) was conducted in December 2016and February 2017. A complete randomised block design was used with 6 replicates per species per treatment: control, treated with bacteria from diseased coral, treated with bacteria from healthy coral and treated with bacteria from both healthy and diseased coral. The number of zooxanthellae was used as indicator. Using one-way ANOVA results showed conclusively that, healthy bacteria isolated from A. asperahas growthpromoting effect ( $\mathrm{F}=13.542 ; \mathrm{p}=.004)$ on zooxanthellae thus sustaining the health of the coral and as inoculum acts as a living entity in the line of defense.
\end{abstract}

Keywords: Biocontrol potential of bacteria, coral mucus, Acropora

\section{Introduction}

Coral is a bio-structure consistingofcoral the host and itssymbiotic organisms that has existed for about 500 million years but continually endureeven though it had been severedfor diseases (Riegl et al., 2009). In the past two decades, coral has become research topic interest to understand the existence of microbes associated to coral, their relationship with the environment and its role for the coralsbene fit. The interest in coral microbiology started since the coral mortality in early 82-83shad been described (Glynn, 1985; Riegl et al., 2009; McClanahan et al., 2001); pathogenic bacteria from some diseased corals were isolated(Kushmaro et al.,1998; Ben-Haim and Rosenberg, 2002; Ben-Haim et al., 2003; Kushmaro et al, 2001; Rosenberg et al., 2007a; Sussman, 2009); also a new trend to find out coral-associated bacteria in their role to protect the coral and increase its capability to adapt to higher environmental temperatures (Rithie, 2006; Rosenberg et al., 2007b; Shnit-Orland and Kushmaro, 2008; Nissimov et al., 2009; Teplitski and Ritchie, 2009; Rypien et al., 2010; Kvennefors et al., 2012).

Coral-associated bacteria is a dynamic relationship in coral that could be either symbiotic or pathogenic. The abundance and diversity of coral associated bacterial was highly noted in numerous studies withspecies-specificity cited in coral, such as those residing in mucus (Bourne and Munn, 2005; Koren and Rosenberg, 2006; Kooperman et al., 2007; Zhang et al., 2015), tissue (Rosenberg et al., 2007b: Littman et al., 2009; Chiu et al., 2012; Krediet et al., 2013, Carlos et al., 2013; Thompson et al., 2015; Wada et al., 2016) and skeleton (Wilson et al., 2012; Li et al., 2014) of the coral. They stay in the coral for space and food. They play significant role in defence against disease.

Some studies done in coral defence are, corals can certainly adapt to the changing of environmental conditions rapidly by altering their population of symbiotic bacteria as coral resistance to disease by using Vibrio shiloi isolated fromOculina patagonica in amodel system of disease(Reshef et al., 2006).Corals may be able to control the colonies of mucus-associated bacteria by altering the composition of the mucus that could support the bacteria that inhibit potential pathogens (Rohwer and Kelly, 2004)

Kvennerfors et al., (2011) investigated members of Pseudoalteromon as and ribo types or group of $\alpha$ proteobacteria isolated from Acropora millepora (Ehrenberg 1834) described as 'type B associates' that may be important functional groups in maintaining microbial communities bydisplaying potent antimicrobial activity against a range of other cultured isolates.

The study of Martínez-Luis et al., (2011) described that Pseudoalteromonas sp.inhibited the growth of pathogenic bacteria, Bacillus subtillis and Vibrio sp. because ofcyclo-(L-Ph-L-Pro) and cyclo-(L-Leu-L-Pro) compoundscontained in the bacteria isolated fromOctocoral,Leptogorgia alba.

Nissimov et al., (2009) reported that 9/ 156 bacteria associated to Oculina patagonicashowedbiocontrol potential ability against V. shiloi.Pseudoalteromonas sp.displayedthe strongest activity of biocontrol potential.

Rypien et al., (2010) described that $69.9 \%$ of 67 bacteriaisolated from Montastrea annularisshowed inhibitory activity against pairwise matches and against pathogenic Vibrio shiloi and V. coraliilyticus. 
Another indicator of coral disease is the declining of coral agent photosynthetic end osymbiont algae or zooxanthellae caused by proximal of thermal breakdown characterized by symptoms of discoloration of pale look or even loss of color altogether. This incident is reflective of coral bleaching which can lead to other disease (Wooldridge, 2013).

Coral symbiontor zooxanthellae of the genus Symbiodinium is an eukaryotic organism normally inhabitingcoral tissue (Baker, 2003; Rosenberg et al., 2004; Winters et al., 2009; Vollmer et al., 2012)atvery high densities (greater than $106 \mathrm{~cm}-2$ ) (Hoegh-Guldberg and Smith, 1989; Wooldridge, 2013). They provide coral the host with nutrition, synthesize and release precursor biochemical, and translo cate fixed carbon to the host (Vollmer et al., 2012).

Zooxanthellae is very dependent on thermal condition, they are expelled from the tissue if temperature reaches 1 to $2{ }^{\circ} \mathrm{C}$ above their normal range (Cervino et al., 2004). Another factor is lightcombined with high temperature in the environmental that will cause the loss of pigments and damage to photo systems.

The zooxanthellae can then be used as an indicator to determinedeterioration in coral health which is called bleaching of hermatypic corals and is known by symptoms such as whitening in corals due to loss of either symbiotic algae or their pigments, or both(Jokiel and York, 1982; Jones, 1997). This severely differs between coral species and might lead to un-recovery and subsequently deathof corals due to seasonal change (Brown, 1997; Hoegh- Guldberg, 1999; Loya et al., 2001; Ralph et al., 2001).

Jones (1997) studied Acropora formosa in the reefs of Magnetic Island, Australia. At the time when water temperature ranged $32-34^{\circ} \mathrm{C}$ the zooxanthellae density decreased during and after bleaching. The same decrease in zooxanthellae densities were observed in Montastrea spp. of the Caribbean corals with infection and increase in temperature (Cervino et al., 2004); also happened during bleaching of $80-90 \%$ colonies of Oculina patagonica in the Mediterranean coast of Israel was directly correlated sea surface temperature was $26-30^{\circ} \mathrm{C}$ (Shenkar et al., 2006).

In using the breakdown of the presence of zooxanthellae or symbiotic algal in understanding the complexity of coral relationships and its associated microbes, this study intended to identify if coral mucus associated bacteria has a biocontrol potential ability to perform a coral defense or none at all and eventually lead to a disease.In this experiment healthy coral is exposed to an open environment and treated accordingly.

The aim of this study was to determine if $\mathrm{H}_{0}$ : there is no significant difference in the number of zooxanthellae in the experiment of corals Acropora millepora (Ehrenberg, 1834) and Acropora aspera (Dana, 1846) by treatment with bacteria from diseased coral, bacteria from healthycoral, combinationof healthy and diseased bacteria compared to a control or if there is a significant difference between each treatmentin the number of zooxanthellae.

\section{Materials and Methods}

\subsection{Fragments Preparation and Transplanting}

Colonies of healthy corals Acropora millepora (Ehrenberg, 1834) (Fig 5.1A) and Acropora aspera (Dana, 1846)(Fig 5.1B) were collected from the reef site of Bantayanbeach; Dumaguete City and the experiments were carried out at the laboratory of the Institute of Environmental and Marine Sciences of Silliman University, Philippines. The coral fragments were then put in a rectangular tank for adjusting the environmental condition within 3-5 days for replanting preparation. For the experiment, a 5-10 cm fragment of each coral (Fig 5.1C) was cut out and was transplanted upon a 7x7 cm square block made of cement (Fig 5.1D). Each fragment then was attached to the block using the combination of marine epoxy and glue. The fragments then immediately were transferred into a plastics container filled with seawater which went in a setting under anexperimental design for different treatments (Fig 1E).

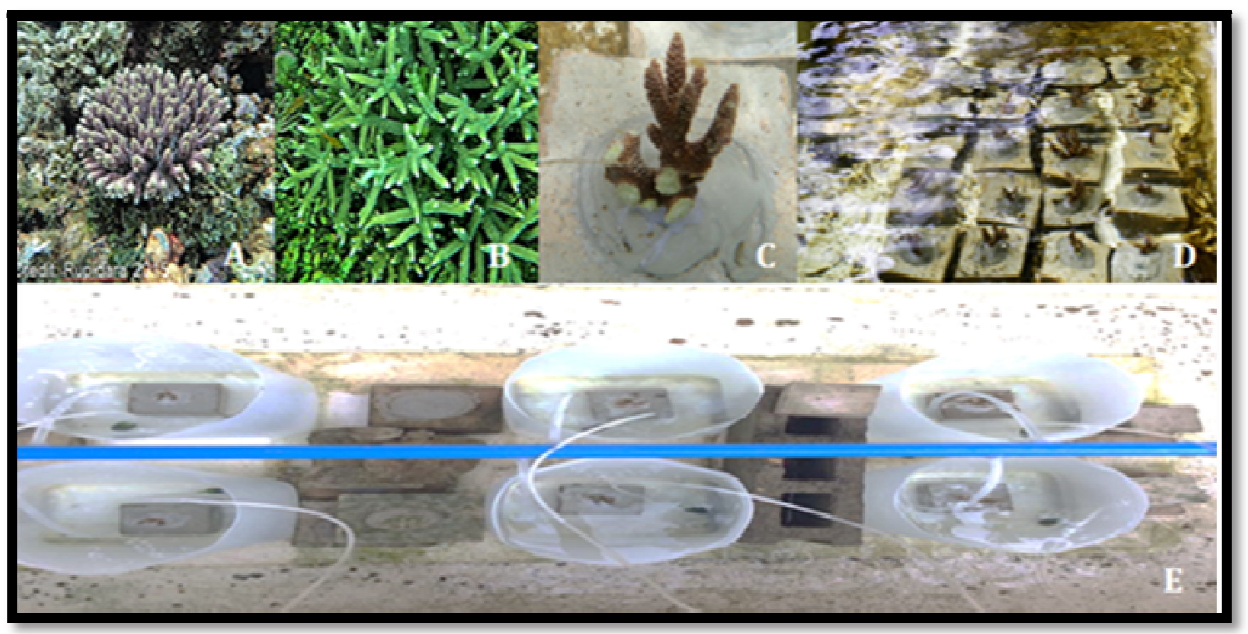

Figure 1: Diagram of Preparation of Coral Transplantation, A) Acropora Millepora, B) Acropora Aspera, C) Coral Fragments, D). Transplanted Coral in Square Block Cement, E) Coral Fragments in Plastic Containers

Six fragments of each coral species went under four different treatments condition with the biocontrol potential species bacteria only, with only the pathogenic species bacteria isolated from diseased coral, combination of the 
pathogenic and biocontrol species bacteria, and without bacteria or control. These fragmentsin plastic containers were filled with seawater and placed in the tanks. Temperature and light were monitored with a HOBO pendant data logger.

\subsection{Experimental Design}

The plastic container contained each coral fragment of A. millepora (Ehrenberg, 1834) and A. as pera (Dana, 1846) for the experimental designs which were selected randomly using lottery method then was set up in a tank (see Figure 5.2). The purpose of random placement is for each coral to have a specific environmental condition where it was placed in open air. The experiment continued for one week.

The experimental design for A. aspera fragments in the plastic container in no. 1-6 was considered as the control group(AC), no. 7-12 were expelled to combine pathogenic bacteria and biocontrol potential bacteria (encoded as AHD), no. 13-18 were treated with biocontrol potential bacteria only (encoded as AH), and no. 19-24 were treated with pathogenic bacteria only (encoded as $\mathrm{AD}$ ).

The experiment using A. millepora was treated as follows:each fragment in the plastic container no. 1-6 were control (MC), no. 7-12 wasadded with pathogenic species bacteria (encoded as MD), no. 13-18 wasadded with biocontrol potential species bacteria (encoded as $\mathrm{MH}$ ) and no. 19-24 were added with combination of pathogenic bacteria and biocontrol potential bacteria (encoded as MHD) (Fig. 2).

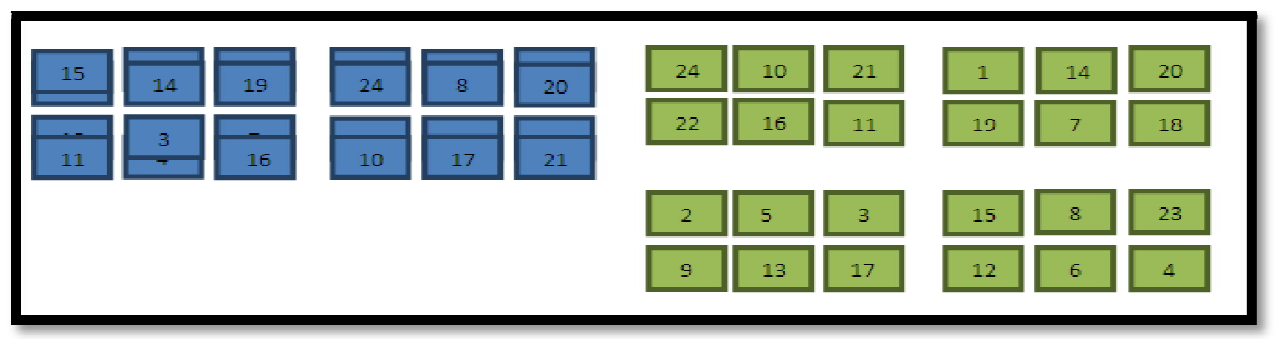

Figure 2: Experimental Design. Blue Color for A. Millepora (Ehrenberg, 1834) and Green for Color A. Aspera (Dana, 1846)

\subsection{Injection Experiment and Mucus Sampling}

Bacteria injection was a modification of Cervino et al., (2004) method. The potential bacteria and pathogenic species bacteria of Acropora millepora (Ehrenberg, 1834) and Acropora aspera (Dana, 1846) were selected using pair wise tests over 9 and 19 bacteria isolated from healthy and diseased, and 24 and 16 bacteria isolated from healthy and diseased corals respectively, were cultured in marine broth and were shaken for $24 \mathrm{~h}$ using a shaker. A total of $0.5 \mathrm{~mL}$ of mixed bacteria of $0.25 \mathrm{~mL}$ from the two cultures pathogenic or biocontrol potential bacteriathen was smeared by pouring it on the surface of each coral (Fig. 3). For the fragments that were treated with the combination of both bacteria, they were first treated with culture of the healthy coral or biocontrol potential bacteria to allow the colonizationfollowed on the next day with the culture of the diseased coral or pathogenic bacteria, to see if the biocontrol culture contributedto healthy condition of the corals. The experiment continued for 5 days.

The inoculation of the pure is olates in this experiment used two isolates that were proven to have the ability as a biocontrol potential against pathogenic bacteria. For fragments of coral A. millepora, the biocontrol potential bacteria were HAM C and HAM F, while the pathogenic bacteria were DAM 8 and DAM 10. The species bacteria that were used for fragments of A. aspera for the biocontrol were HAAE and HAA V and for the pathogenic bacteria were DAA1 and DAA13.

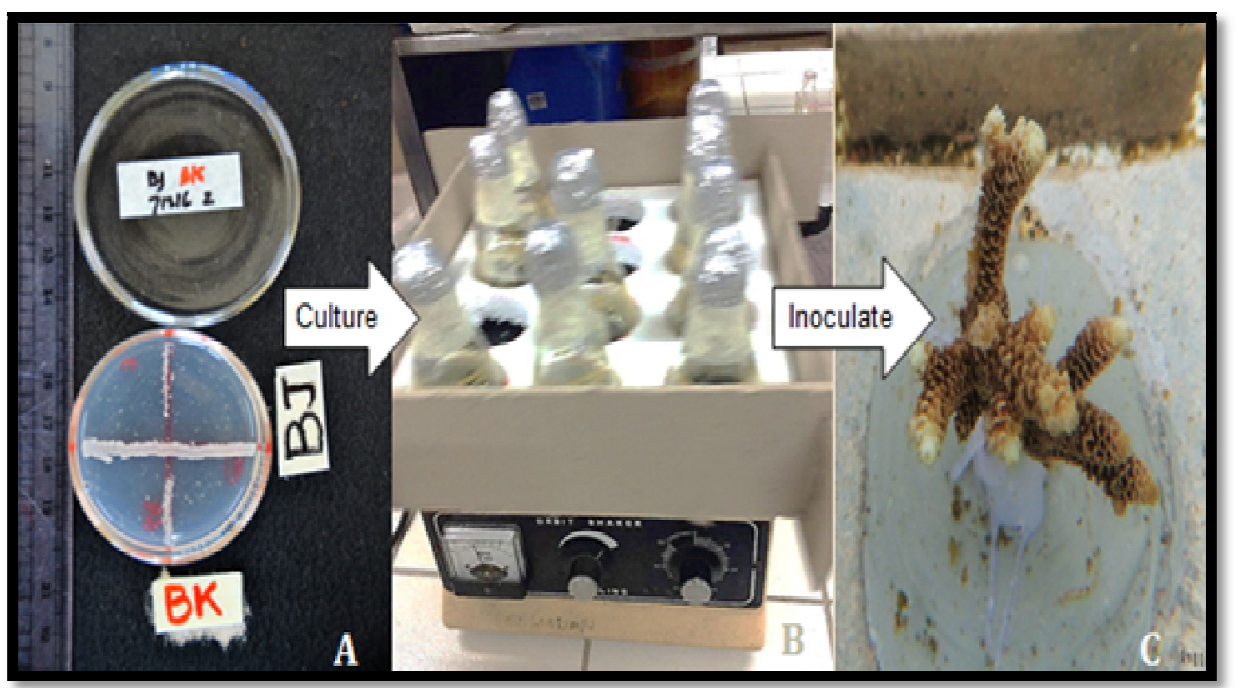

Figure 3: Bacteria Inoculation and Injection Process. A) Bacteria Growth in Petri Dish, B) Bacteria Broth Culture, C) Inoculation 
A $19 \mathrm{~mL}$ of coral mucus was collected from the surface of the coral fragment in the container early in the morning between 7.10 to $7.30 \mathrm{AM}$ by using a sterile syringe without a needle and then right after that the mucus samples were directly brought to the laboratory for centrifugation. Samplings were done on the first day after coral transplantation (T1), the day after the injection and day $5^{\text {th }}$ (T5) of the one week experiment (Fig.4).

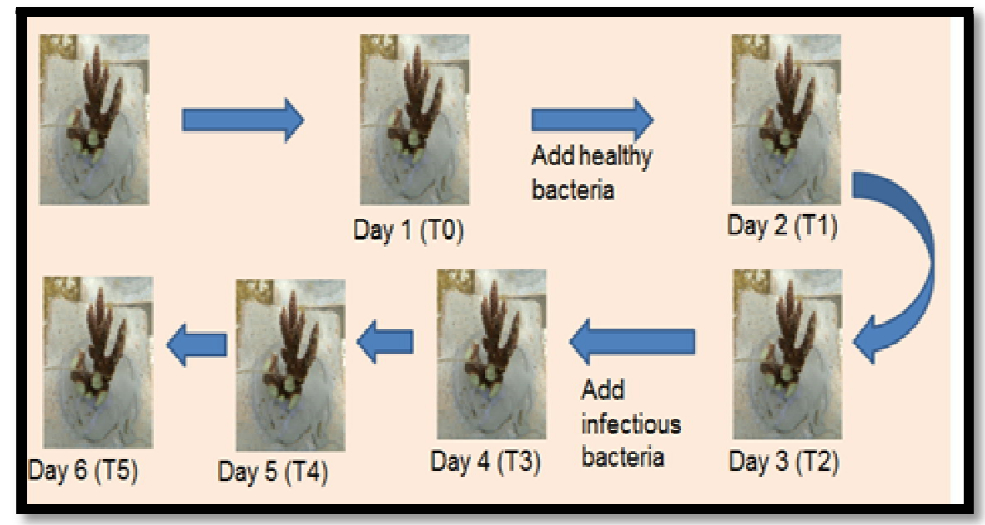

Figure 4: Sampling Scheme of the Experiment

\subsection{The Counting of Zooxanthellae Cells}

A modified method of Cervino et al., (2004), Jones, (1997) and Shenkar et al., (2006) were employed to quantify the number of zooxanthellae in the mucus as an indicator of the effect of the biocontrol potential of the bacteria. Mucus samples that were collected were taken to the laboratory and then centrifuged for 15 minutes at $3000 \mathrm{rpm}$ using an International Clinical centrifuge no.W7531, to retrieve the pellets (Fig. 5).To the mucus pellets were added with $1 \mathrm{mLof}$ $10 \%$ formalin to preserve the zooxanthellae, then vortexed to completely mix. An aliquot of one drop of the sample was examined under HPO using a Motic microscope CAT no. 7101 Sail brand with 40x10 lens magnification. The number of zooxanthellae in 5HPO field were counted. Three replicates of 1 drop each were examined and the counts averaged.

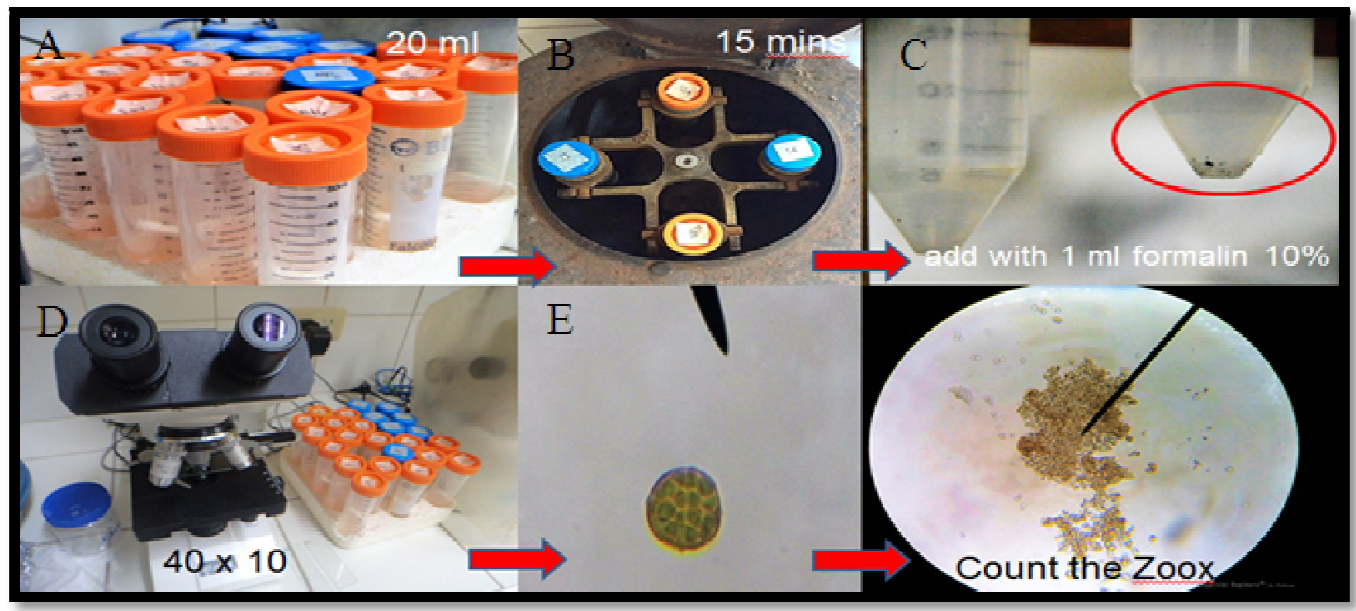

Figure 5: The Extraction of Zooxanthellae.A) 19 Ml of Samples, B) Centrifugation,

C) Pellets Added with 1 Ml Of 10\% Formalin, D) Examined the Number of

Zooxanthellae under HPO Using a Motic Microscope, E (100) X), F (100x) the Zooxanthellae

\subsection{Statistical Analysis}

Relative densities per treatment were then compared using One-way ANOVA. All statistical analyses were performed using SPSS. The dependent factor was the number of zooxanthella and the independent factor was thetreatment (bacterial culture that was added) and compared with the control group. Level of significance was set at 0.05.

\section{Results}

\subsection{The Zooxanthellae}

Thenumber of zooxanthellae was countedwhere a decrease or increase is a determinant of the ability ofbiological control potential.

The zooxanthellae were described as having variety of colors yellowish - brown that was determined under 40x10 lens magnification microscope. It was shown that there were differences between zooxanthellae of coral A. millepora and A. aspera both in number and color (Fig6). 


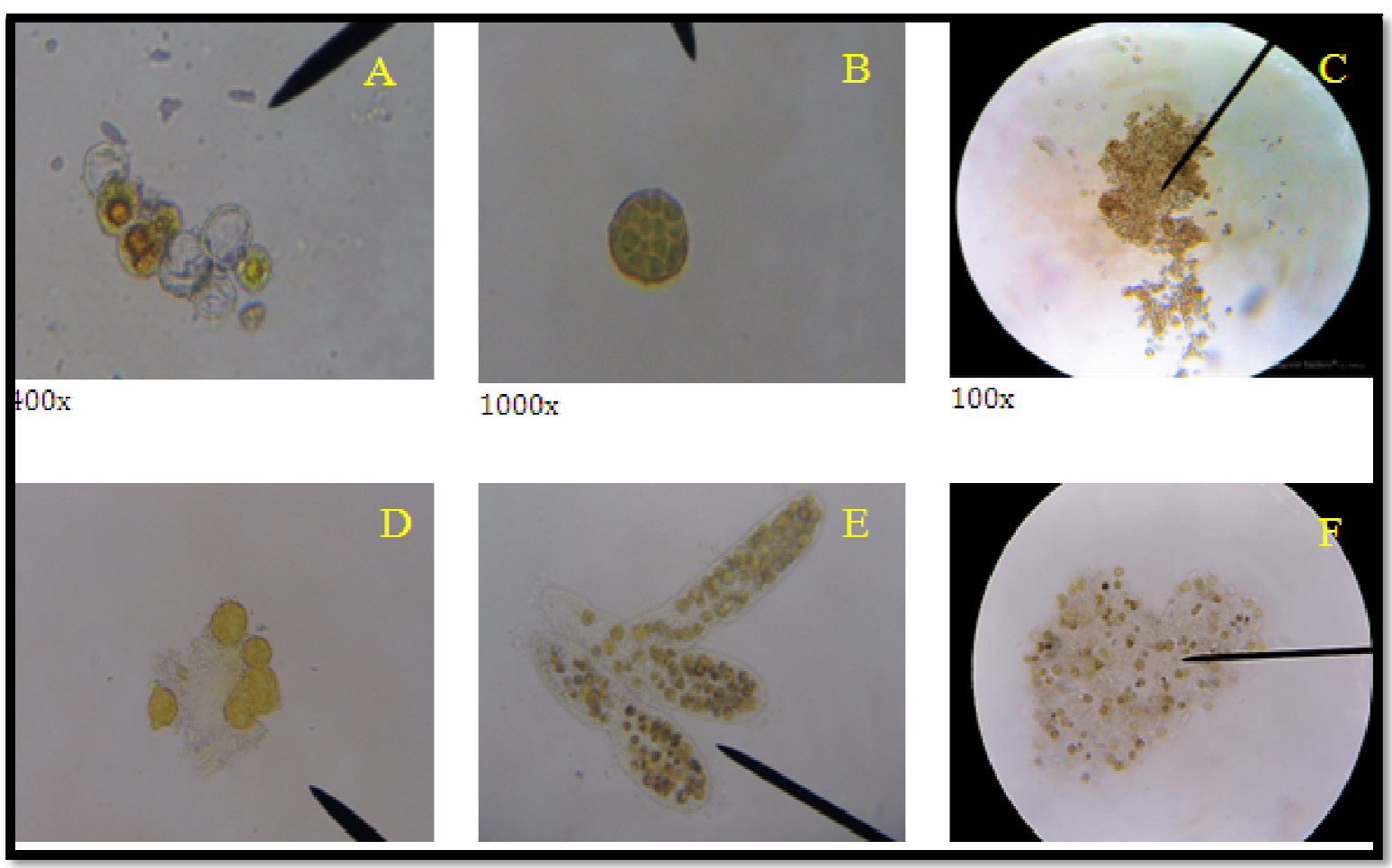

Figure 6: Pictures of Zooxanthellae Found In the Experiment of Coral A.

Millepora (Ehrenberg, 1834) (A, B, C) and Coral A. Aspera (Dana, 1846) (D, E, F)

\subsection{The Challenge Experiment on the Fragments of Acropora Aspera (Dana, 1846)}

The experiment on the fragments of A. aspera without bacterial treatment (AC) showed that the mean number of zooxanthellae was higher on the first day than fifth day of sampling (Table 5.1, Fig. 5.7 and Appendix 5). The result of the One-way analysis of variance (ANOVA) (Table 5.2) test on the number of zooxanthellae in AC indicated there was no significant difference $(F(1,10)=0.725$ Sig. $(p) 0.415>0.05)$.

The mean number of zooxanthellae in coral fragments treated with bacterial isolates from healthy A. aspera (AH) was higher in day fifth than first day of sampling. ANOVA test indicated the difference and was statistically significant ( $F$ $(1,10)=13.542$ Sig.(p) $0.004<0.05)$.

The mean number of zooxanthellae in coral fragments treated with bacterial isolates from diseased A. aspera(AD) was higher on the firstday of sampling compared to fifth day. However, this was not statistically significant $(\mathrm{F}(1,10)=$ 0.145 Sig.(p) $0.711>0.05$ ).

The mean number of zooxanthellaein coral fragments treated with combination of the bacterial isolates from the mucus of healthy and diseased A. aspera(AHD) was higher on the first day of sampling thanthe fifth day. However, this was not statistically significant $(F(1.10)=0.005$ Sig.(p) $0.946>0.05)$.

\begin{tabular}{|c|c|c|c|c|}
\hline Day & AC & AH & AD & AHD \\
\hline 1 & $137.17 \pm 64.577$ & $168.33 \pm 66.096$ & $127.50 \pm 99.532$ & $168.83 \pm 36.581$ \\
\hline 5 & $114.00 \pm 16.565$ & $308.00 \pm 65.379$ & $111.50 \pm 26.167$ & $167.17 \pm 45.460$ \\
\hline Levene statistics & $4.376(\mathrm{p}=.063)$ & $.046(\mathrm{p}=.835)$ & $2.481(\mathrm{p}=.146)$ & $.160(\mathrm{p}=.698)$ \\
\hline
\end{tabular}

Table 1: Mean \pm Standard Deviation of the Number of Zooxanthellae in Acropora Aspera (Dana, 1846)

Groups AC = A. Aspera for Control; AH =A. Aspera Treated with Healthy Bacteria,

$\mathrm{AD}=\mathrm{A}$. Aspera Treated with Diseased Bacteria; $\mathrm{AHD}=\mathrm{A}$. Aspera Treated with

Healthy and Diseased Bacteria

Homogeneity variance of mean of the number of zooxanthellae in group experiment of Acropora as pera fragments showed with Levene's test that for all treatments the Sig. value werehigher than alpha of .05 ( $p>.05)$, the null hypothesis (no difference) for the assumption of homogeneity of variance is retained.There is no significant difference between group's variances or the homogeneity of variance was assumed (table 5.4). 


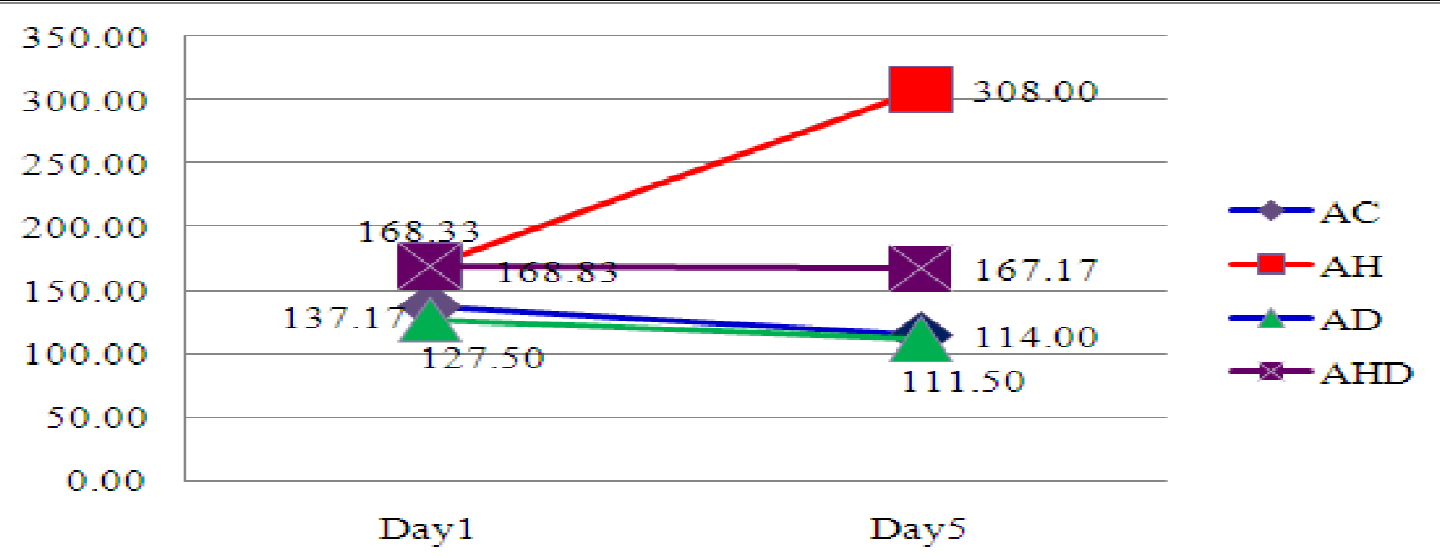

Figure 7: Line Graphic Mean of the Number of Zooxanthellae in Acropora Aspera (Dana, 1846)

Groups, AC =A. Aspera for Control, AH =A. Aspera Treated with Healthy Bacteria,

$\mathrm{AD}=\mathrm{A}$. Aspera Treated with Diseased Bacteria, $\mathrm{AHD}=\mathrm{A}$. Aspera Treated with Healthy and Diseased Bacteria

\begin{tabular}{|c|c|c|c|}
\hline Treatments & F & Sig. & P value \\
\hline $\mathrm{AC}$ & .725 & .415 & .05 \\
\hline $\mathrm{AH}$ & 13.542 & $.004^{*}$ & \\
\hline $\mathrm{AD}$ & .145 & .711 & \\
\hline $\mathrm{AHD}$ & .005 & .946 & \\
\hline
\end{tabular}

Table 2: Results of One-Way ANOVA Test Foracropora Aspera

(Dana, 1846) Group 5 Days after Treatments

*Significant Different

\subsection{The Challenge Experiment on the Fragments of Acropora Millepora (Ehrenberg, 1834)}

The experiment on the fragments of A. millepora without bacterial treatment (MC) showed that the mean number of zooxanthellae was higher on the first day than day fifth (Table 5.3, Fig. 5.8 and Appendix6). The result of the One-way analysis of variance (ANOVA) (Table 5.4) test on the number of zooxanthellae in AC indicated the difference and was statistically significant $(F(1,10)=10.979$ Sig. $(p) 0.008<0.05)$.

The mean number of zooxanthellaein coral fragments treated with bacterial isolates from the mucus of healthy A. millepora $(\mathrm{MH})$ was higher in day fifth than day first. However, this was not statistically significant $\mathrm{F}(1,10)=4.664 \mathrm{Sig}$. (p) $0.056>0.05$ ).

The mean number of zooxanthellae in coral fragments treated with bacterial isolates from the mucus of diseased A. millepora(MD) was higher in the day first compared to day fifth. ANOVA test indicated the different and was statistically significant $(F(1,10)=47.646$ Sig. $(p) 0.000 \varangle 0.05)$.

The mean number of zooxanthellae in coral fragments treated with combination of bacterial isolates from the mucus of healthy and diseased A. millepora(MHD) was higher in day fifth than day first. However, this was not statistically significantF $(1,10)=.055$ Sig. (p) $0.820>0.05)$.

\begin{tabular}{|c|c|c|c|c|}
\hline Day & MC & MH & MD & MHD \\
\hline 1 & $274.00 \pm 41.933$ & $215.17 \pm 59.115$ & $297.83 \pm 59.801$ & $222.00 \pm 56.391$ \\
\hline 5 & $131.00 \pm 97.040$ & $391.83 \pm 191.450$ & $122.00 \pm 17.810$ & $237.83 \pm 156.011$ \\
\hline Levene statistics & $1.339(\mathrm{p}=.274)$ & $3.315(\mathrm{p}=.099)$ & $3.242(\mathrm{p}=.102)$ & $2.181(\mathrm{p}=.171)$ \\
\hline
\end{tabular}

Table 3: Mean \pm Standard Deviation of the Number of Zooxanthellae in Acropora Millepora

(Ehrenberg, 1834) Groups, MC =A. Millepora for Control, $\mathrm{MH}=$ A Millepora Treated with Healthy Bacteria; $\mathrm{MD}=$ A. Millepora Treated with Diseased Bacteria, MHD =A. Millepora Treated with Healthy and Diseased Bacteria

Homogeneity variance of mean of the number of zooxanthellae in group experiment of A.millepora fragments showed that Levene's test for all treatments showed that the Sig. value were higher than alpha of .05 ( $p>.05)$, the null hypothesis (no difference) for the assumption of homogeneity of variance is retain and conclude that there is no significant difference between group's variances or the homogeneity of variance was assumed (table 3). 


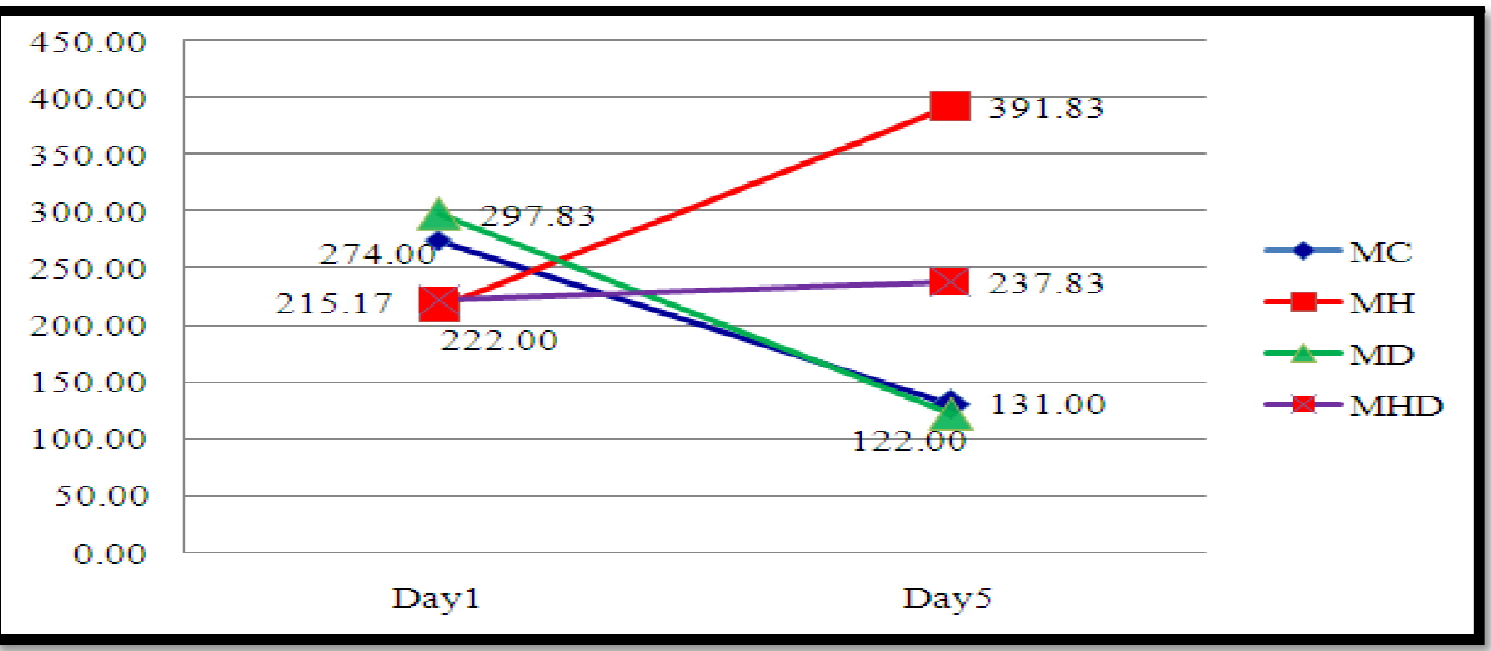

Figure 8: Line Graphic Mean of the Number of Zooxanthellae in Acropora Millepora (Ehrenberg, 1834) Groups, $\mathrm{MC}=\mathrm{A}$. Millepora for Control, $\mathrm{MH}=\mathrm{A}$. Millepora Treated with Healthy Bacteria, $\mathrm{MD}=\mathrm{A}$. Millepora Treated with Diseased Bacteria; MHD =A. Millepora

Treated with Healthy and Diseased Bacteria

\begin{tabular}{|c|c|c|c|}
\hline Treatments & F & Sig. & Pvalue \\
\hline MC & 10.979 & $.008^{*}$ & .05 \\
\hline MH & 4.664 & .056 & \\
\hline MD & 47.646 & $.000^{*}$ & \\
\hline MHD & .055 & .820 & \\
\hline
\end{tabular}

Table 4 Results of One-Way ANOVA Test for Acropora Millepora

(Ehrenberg, 1834) Group 5 Days after Treatments

*Significant Different

\section{Discussion}

The biocontrol potential experiments showedthat the number of zooxanthellae was affected when challenged with the bacterial isolates used to treat the coral fragments.

The number of zooxanthellae in the A.aspera coralfragments treated with bacterial isolates (HAA E and V) from healthy coral (AH treatment) increased twofold. This clearly illustrated that the bacteria was promoting the growth of the zooxanthellae. However, when these bacteria were co-inoculated with the isolates from diseased corals (DAA 1 and 13) the growth promoting ability was affected as shown bythe slight decrease in the number of zooxanthellae (AHD treatment). However, this was statistically insignificant (Table 5.1, 5.2; Fig 5.7).

It is evident in this experiment that the bacterial isolates (DAA 1 and 13) from diseased corals were destructive to the zooxanthellae.

The number of zooxanthellae in the A. millepora coral fragments treated with bacteria isolates (HAM C and F) from healthy coral ( $\mathrm{MH}$ treatment) also increased. While promoting the growth of zooxanthellae these isolates also inhibited the effect of the bacterial isolates from diseased corals (DAM 8 and 10) since the number of zooxanthellae in MHD treatment increased. However, this was statistically insignificant (Table 5.3, 5.4; Fig 5.8).

The bacterial isolates from the diseased corals (DAM 8 and 10)were destructive to the zooxanthellae (MD treatment) as shown by the $243 \%$ decrease in the number of zooxanthellae.

The decrease in the number of zooxanthellae of the untreated coral fragments (AC and MC treatments) may have been attributed to a local disturbance in the individual plastic containers where the coral fragments were placed.

Even though the statistical test rendered the mean number of the zooxanthellae unreliable the biocontrol potential of HAA E and V, HAM C and F seemed to be demonstrated in isolated cases. These experiments need to be further verified with more replicates. The coral fragments were placed in individual plastic containers which might have led to fluctuations in physical conditions.

\section{Conclusion} in results.

The challenge experiments on the fragments of corals of A. millepora and A. as pera were not altogether uniform

It was remarkable to note that the inoculation with isolates from healthy A. millepora and A.aspera were promoting the growth of the zooxanthellae although statistics indicated significant result only in the case of A. aspera. This still suggests that the bacterial isolates found in healthy corals contribute to the healthy conditionof the coral by their growth promoting ability on the zooxanthellae. When the zooxanthellae growth is stimulated and promoted, the health of the coral is sustained regardless of a pathogen that needs to colonize first or in this experiment the inoculation of isolates from diseased coral DAA 1 and DAA 13. Their co-inoculation showed a minimal decrease of less than $1 \%(p=0.698)$ of zooxanthellae. This certainly needs further examination. 
The co-inoculation of isolates from both healthy and diseased coral was most interesting since their effect on zooxanthellae count will reveal the prominence in effect of either isolates from healthy or diseased corals. From the slight increase of $7 \%(\mathrm{p}=0.171)$ in zooxanthellae count in A. millepora one can be surmise that HAM C and HAM F possess biocontrol potential over DAM 8 and 10. These results require further investigation with more samples, using methods for determining specificity of the biocontrol activity, or using other indicators such as mitotic index and chlorophyll content in the zooxanthellae as used by the other authors (Shenkar et al., 2006; Cervino et al., 2004; Jones 1997). This will substantiate the effectivity of biocontrol activity.There were extraneous circumstances in the experimental conditions that were not avoided and might have required extended pre-experimental trials.

The inoculation with isolates from mucus of diseased A. aspera and A. millepora were definitely destructive to the zooxanthellae population. The statistical test result requires further verification such as sample sizeincrease.

\section{Acknowledgements}

This research was funded by UBCHEA and Artha Wacana Christian University, Kupang, East Nusa Tenggara, Indonesia. The researcher would like to highly honour to Dr. Hilconida P. Calumpong and Dr. Janet S. Estacion for experimental design advised and also special thank for Sir Frankie J. Salean, SE, MP, Rector of Artha Wacana Christian University.Thankyoufor experiment assists toSir Monet, Sir Mating, Elmer and Manong Coro.

\section{References}

i. Baker, A.C. 2003. Flexibility and specificity in coral-algal symbiosis: Diversity, ecology, and biogeography of Symbiodinium. Annual Review of Ecology, Evolution, and Systematics, 34, 661-689. doi: 10.1146/ annurev.ecolsys.34.011802.132417.

ii. Ben-Haim, Y., Zicherman-Keren, M., Rosenberg, E. 2003. Temperature-regulated bleaching and lysis of the coral Pocillopora damicornis by the novel pathogen Vibrio coralliilyticus. Appl. Environ. Microbiol, 2003 Jul;69(7), 4236-4242. doi: 10.1128/ AEM.69.7.4236-4242.2003

iii. Ben-Haim, Y, Rosenberg, E. 2002. A novel Vibrio sp. pathogen of the coral Pocillopora damicornis. Marine Biology, $141(1), 47-55$.

iv. Ben-Haim, Y., Banim, E., Kushmaro, A., Loya, Y., Rosenberg, E. 1999. Inhibition of photosynthesis and bleaching of zooxanthellae by the coral pathogen Vibrio shiloi. Environmental Microbiology, (1999) 1(3), 223-229.

v. Bourne, D.G., Munn, C.B. 2005. Diversity of bacteria associated with the coral Pocillopora damicornis from the Great Barrier Reef. Environmental Microbiology, 7(8), 1162-1174. doi: 10.1111/j.14622920.2005.00793

vi. Brown, B. E. 1997. Coral bleaching: Causes and consequences. Coral Reefs 16 (suppl.). S129-S138.

vii. Carlos, C., Torres, T.T., Ottoboni, L.M.M. 2013. Bacterial communities and species-specific associations with the mucus of Brazilian coral species. Scientific Reports, 3(1624), 1-7. doi:10.1038/ srep01624.

viii. Cervino, J.M., Hayes, R.L., Polson, S.W., Goreau, T.J., Martinez, R.J., Smith G.W. 2004. Relationship of Vibrio species infection and elevated temperatures to Yellow Blotch/Band disease in Caribbean corals.Appl. Environ. Microbiol.,70(11),6855-6864. doi: 10.1128/ AEM.70.11.6855-6864.2004.

ix. Chiu, J.M.Y., Li, S., Li, A., Po, B., Zhang, R, Shin, P.K.S., 2012. Bacteria associated with skeletal tissue growth anomalies in the coral Platygyra carnosus. FEMS Microbiol. Ecol., 79, 380-391. doi: 10.1111/j.15746941.2011.01225.x.

x. Glynn, P. W. 1985. El Nino-associated disturbance to coral reefs and post disturbance mortality by Acanthaster planci Mar. Ecol. Prog. Ser. Published October 17,1985, 26, 295-300.

xi. Goreau, T.J. Hayes, R.L. 1994. Coral bleaching and ocean "Hot Spots". Ambio-Journal of Human Environment $\begin{array}{llll}\text { Research } \text { Management, 23, 176-180. } & \text { 23 }\end{array}$ http:/ / www.botany.hawaii.edu/ basch/ uhnpscesu/ pdfs/ sam/ Goreau1994bS.pdf (Accessed 2015)

xii. Hayes, R.L., Goreau, N.I., 1998. The significance of emerging diseases in the tropical coral reef ecosystem. Revista de Biologia Tropical 46 (Suppl. 5), 173-185.

xiii. Hoegh-Guldberg, O. 1999. Climate change, coral bleaching and the future of the world's coral reefs. Marine and Freshwater Research, 50, 839-866.

xiv. Hoegh-Guldberg, O., Smith, G.J., 1989. Light, salinity, and temperature and the population density, metabolisms and export of zooxanthellae from Stylophora pistillata (Esper, 1797) and Seriatopora hystrix (Dana 1846). Journal of Experimental Marine Biology and Ecology ,129, 279-303.

xv. Hughes, T.P., Baird, A.H., Bellwood, D.R., Card, M., Connolly, S.R., Folke, C., Grosberg, R., Hoegh-Guldberg, O., Jackson, J.B., Kleypas, J., 2003. Climate change, human impacts, and the resilience of coral reefs. Science 301, 929933.

xvi. Jokiel, P.L., York,R.H. 1982. Solar ultraviolet photobiology of the reef coral Pocillopora damicornis and symbiotic zooxanthellae. Bull. Mar. Sci.,32, 301-315.

xvii. Jones, R. J. 1997. Changes in zooxanthellae densities and chlorophyll concentrations in corals during and after a bleaching event. Mar. Ecol. Prog. Ser.,158, 51-59.

xviii. Kleypas, J.A., Mcmanus, J.W., Menezf, L.A.B. 1999. Environmental limits to coral reef development: Where do we drawthe line? Amer. Zool., 39, 146-159.

xix. Kooperman, N., Ben-Dov,E., Kramarsky-Winter, E.,Barak, Z., Kushmaro, A.,2007. Coral mucus-associated bacterial communities from natural and aquarium environments. FEMS Microbiol Letters, 276(1),106-113. doi: 10.1111/j.1574-6968.2007.00921.x 
xx. Koren, O., Rosenberg, E. 2006. Bacteria associated with mucus and tissues of the coral Oculina patagonica in summer and winter. Applied And Environmental Microbiology, 72(8), 5254 - 5259. doi:10.1128/ AEM.00554-06.

xxi. Krediet, C.J., Ritchie, K.B., Paul, V.J., Teplitski, M. 2013. Coral-associated micro- organisms and their roles in promoting coral health and thwarting diseases. Proc. R. Soc. B., 280, 20122328.http:/ / dx.doi.org/ 10.1098/ rspb.2012.2328(Accessed 2015)

xxii. Kushmaro, A., Banin, E., Loya, Y., Stackebrandt, E., Rosenberg, E. 2001. Vibrio shiloi sp. nov., the causative agent of bleaching of the coral Oculina patagonica. International Journal of Systematic and Evolutionary Microbiology (2001), 51, 1383-1388.

xxiii. Kushmaro, A., Rosenberg, E., Fine, M., Ben-Haim, Y., Loya, Y. 1998. Effect of temperature on bleaching of the coral Oculina patagonica by Vibrio shiloi AK-1. Mar. Ecol. Prog. Ser. 171, 131-137.

xxiv. Kvennefors, E., E. Sampayo, C. Kerr, G. Vieira, G. Roff, Barnes, A.. 2012. Regulation of bacterial communities through antimicrobial activity by the coral holobiont. Microb. Ecol.63, 605- 618

xxv. Li, J., Chen, Q, Li-Juan Long, Jun-De Dong, Jian Yang, Zhang, S. 2014. Bacterial dynamics within the mucus, tissue and skeleton of the coral Porites lutea during different seasons. Scientific Reports, 4 (7320), 1-8. doi: 10.1038/ srep07320

xxvi. Littman, R.A., Wills, B.A., Pfeffer, C., Bourne, D.G. 2009. Diversities of coral-associated bacteria differ with location, but not species, for three acroporid corals on the Great Barrier Reef. FEMS Microbiol, Ecol., 68, 152 - 163.

xxvii. Loya, Y., Sakai, K., Yamazato, K., Nakano, Y., Sembali, H., van Woesik. R. 2001. Coral bleaching: The winners and losers. Ecology Letters 4, 122-131.

xxviii. Martínez-Luis, S., Ballesteros, J., Gutiérrez, M., 2011. Antibacterial constituents from the octocoral-associated bacteriumPseudoalteromonas sp.Rev. Latinoam quím 39 , 1-2, Naucalpan de Juárez 2011.

xxix. McClanahan, T.R., Muthiga, N.A., Mangi, S. 2001. Coral and algal changes after 1998 coral bleaching: Interaction with reef management and herbivores on Kenyan Reefs. Coral Reefs 19, 380-391. doi 10.1007/ s003380000133

xxx. Nissimov, J., Rosenberg, E., Munn, C.B. 2009. Antimicrobial properties or resident coral mucus bacteria of Oculina patagonica. Research letter. FEMS Mirobiol. Lett., 292, 210-215.

xxxi. Ralph, P.J., Gademann, R., Larkum, A.W.D., 2001. Zooxanthellae expelled from bleached corals at $33^{\circ} \mathrm{Care}$ photosynthetically competent. Mar. Ecol. Prog.Ser.,220, 163-168.

xxxii. Reshef, L., Koren, O., Loya, Y., Zilber-Rosenberg, I., Rosenberg, E. 2006. The coral probiotic hypothesis. Environ. Microbiol., 8, 2068-2073.

xxxiii. Riegl, B., Bruckner, A., Coles, S.L., Renaud, P., Dodgea, R.E., 2009. Coral reefs threats and conservation in an era of global change. The year in ecology and conservation biology.Ann. N.Y. Acad. Sci., 1162, 136-186 (2009). doi: 10.1111/j.1749-6632.2009.04493.x c 20

xxxiv. Ritchie, K.B. 2006. Regulation of microbial populations by coral surface mucus and mucus-associated bacteria. Mar. Ecol. Prog. Ser., 322, 1-14.

xxxv. Rohwer, F., Kelley, S. 2004. Culture-independent analyses of coral-associated microbes. In: E. Rosenberg, andY. Loya, (Eds). Coral health and disease (p. 265-75). Heidelberg (Germany): SpringerVerlag

xxxvi. Rosenberg, E., Kellogg, C.A., Rohwer, F. 2007a. Coral microbiology. Oceanography, 20, 146-154. doi: org/ 10.5670/ oceanog.2007.60.

xxxvii. Rosenberg, E., Koren, O., Reshef, L., Efrony, R., Zilber-Rosenberg, I. 2007b. The role of microorganisms in coral health, disease and evolution. Nature reviews Microbiology, 5,355-362.

xxxviii. Rypien, K.L., Ward, J.R., Azam, F. 2010. Antagonist internations among coral-associated bacteria. Environment Microbiology, 12(1), 28 - 39. doi:10.1111/j.1462-2920.2009.02027.x

xxxix. Shenkar, N., M. Fine, M, Kramarsky-Winter, E., Y. Loya, Y., 2006. Population dynamics of zooxanthellae during a bacterial bleaching event. Coral Reefs (2006) 25, 223-227. doi: 10.1007/ s00338-006-0090-0

xl. Shnit-Orland, M., Kushmaro, A. 2008. Coral mucus-associated bacteria: a possible first line of defense. FEMS Microbiol. Ecol., 67, 371-380. doi:10.1111/ j.1574-6941.2008.00644.x

xli. Sokolow, S. 2009. Effects of a changing climate on the dynamics of coral infectious disease: a review of the evidence. Dis. Aquat. Org., 87, 5-18. doi: 10.3354/ dao02099.

xlii. Sussman, M.. 2009. Coral disease pathogen of the Indo-Pacific. James Cook University, Australia; Ph.D thesis. Retrieved from http:// eprints.jcu.edu.au/ 8197

xliii. Teplitski, M., Ritchie, K., 2009. How feasible is the biological control of coral diseases? Trends Ecol. Evol., 2009 Jul,24(7), 378-385. doi: 10.1016/j.tree.2009.02.008.

xliv. Thompson, J.R., Rivera, H.E., Closek, C.J., Medina, M., 2015. Microbes in the coral holobiont: Partners through evolution, development, and ecological interactions. Frontiers in Cellular and Infection Microbiology, January2015, 4 (176), 1-20. doi: 10.3389/ fcimb.2014.00176

xlv. Vollmer, S.V., Baker, A.C., Coffroth, M.A., Harvell, C.D., Medina, M., 2012. Understanding the Coral Holobiont through Science and Scuba. Smithsonian Contributions to the Marine Sciences,39, 173-186.

xlvi. Wada, N., Kawamoto, T., Sato, Y. 2016. A novel application of a cryosectioning technique to undecalcified coral specimens. Mar. Biol., (2016) 163,117. doi:10.1007/ s00227-016-2895-x

xlvii. Wilson, B., Aeby, G.S., Work, T.M.,Bourne, D.G., 2012. Bacterial communities associated with healthy and Acropora white syndrome-affected corals from American Samoa. FEMS Microbiol. Ecol. 80 (2012), 509-520. doi: 10.1111/j.1574-6941.2012.01319.x 
xlviii. Winters, G., Beer, S., Zvi, B.B., Brickner, I., Loya, Y., 2009. Spatial and temporal photoacclimation of Stylophora pistillata: zooxanthella size, pigmentation, location and clade. MEPS 384,107-119 (2009). doi: https:/ / doi.org/ 10.3354/ meps08036.

xlix. Wooldridge, S.A. 2013. Breakdown of the coral-algae symbiosis: towards formalising a linkage between warmwater bleaching thresholds and the growth rate of the intracellular zooxanthellae. Biogeosciences, 10, 1647-1658, doi:10.5194/ bg-10-1647-2013. Retrieved from www.biogeosciences.net/ 10/ 1647/ 2013/

l. Zhang, Y.Y., Ling, J., Yang, Q.S., Wang, Y.S., Sun, C.C., Sun, H.Y., Feng, J.B., Jiang, Y.F., Zhang, Y.F., Wu, M.L., Dong, J.D. 2015. The diversity of coral associated bacteria and the environmental factors affect their community variation. Ecotoxicology. 2015 Oct; 24, (7-8), 1467-77. doi: 10.1007/s10646-015-1454-4. 